\title{
The 'Ajamization of Islam in Ethiopia through Esoteric Textual Manifestations in Two Collections of Ethiopian Arabic Manuscripts
}

\author{
Adday Hernández \\ University of Copenhagen \\ xkr267@hum.ku.dk
}

\begin{abstract}
While the word 'Ajami traditionally refers to texts in many languages written with the modified Arabic script, the meaning has been expanded in the concept of Ajamization used in this volume. 'Ajamization is construed in this article, as it is operationalized in the volume, to refer to the various tangible and subtle enrichments of Islam, its culture, and its written and artistic traditions in Africa. ${ }^{1}$ In this sense, it is not only the modification (enrichment) of the Arabic script that defines 'Ajamization, but also other features such as the content and the aesthetics of the texts. This paper focuses on the cultural dimension of 'Ajamization in two collections of Ethiopian Islamic texts written in Arabic. ${ }^{2}$ These texts encompass magic-related materials, including theurgic texts and invocations to jinn. ${ }^{3}$ I will examine these texts to ascertain whether they reflect a local cosmology, even if they are not written in 'Ajamī but in Arabic. ${ }^{4}$
\end{abstract}

1 For more information on the concept of 'Ajamization, see the introduction of this volume; and Fallou Ngom, Muslims beyond the Arab World: The Odyssey of Ajami and the Muridiyya, Oxford Scholarship Online: June 2016.

2 This article developed from the project "Islam in the Horn of Africa: A Comparative Literary Approach" (IslHornAfr, European Research Council Advanced Grant no. 322849, 2013-2018, PI Alessandro Gori), http://www.islhornafr.eu/index.html.

3 The term "theurgy" has no specific translation in Arabic and therefore the meaning may vary depending on the context. In this paper I will refer to it in the sense of "magic for demanding God's favor which is only based on His power". On the meanings of "theurgy," see John D. Martin III, op. cit., 5. Despite the debates regarding magical terminology, I will employ the terms "amulet" and "talisman" as synonyms in this paper. For more information on the traditions of amulet-making in Islamic Africa and Yemen, see Hamès, Constant, ed. Coran et Talismans: Textes et Pratiques Magiques en Milieu Musulman, Paris, Éditions Karthala, 2007.

4 There are a few sample devotional 'Ajamī texts in the two collections. But they are not the focus of this paper. 


\section{Keywords}

'Ajamization - Ethiopia - Islam - manuscript - Harar - jinn - esoteric - Oromo amulet - Christianity

\section{Introduction}

One of the two collections examined in this article is the Arabic section of the manuscripts gathered by Barbara and Gerald Weiner, of which we have catalogued 198 codices that were acquired in Harar. ${ }^{5}$ The other one is the Arabic section of the manuscripts preserved by the Institute of Ethiopian Studies (IES). ${ }^{6}$ Some of the manuscripts in the IES collection were also acquired in the city of Harar. ${ }^{7}$ The major part of the manuscripts were copied between the eighteenth and twentieth centuries.

Despite the numerous manuscripts containing esoteric textual manifestations that come from Harar, known as the most important Islamic center of knowledge in Abyssinia, it is usually not possible to discern whether these were produced there or were taken to Harar from other locations such as Wallo or the closest sites in Oromia, since the city is independent yet surrounded by Oromo territory. The ownership statements in some of the codices and the spread of certain works in different areas of Ethiopia offer the only clues to the history of these manuscripts. The materials of the Weiner collection, for example, were acquired in Harar, which has been considered the center of religious propagation among the Oromo people ${ }^{8}$ but the ownership statements

5 Mr. Gerald Weiner is a financier and philanthropist in Chicago, Illinois, USA who has acquired more than 200 Arabic manuscripts for Ethiopia and donated them to the Young Research Library at University of California, Los Angeles. Around fourteen manuscripts (7\%) of this collection contain esoteric textual manifestations.

6 The Institute of Ethiopian Studies (IES) is part of the Addis Ababa University. Around 180 manuscripts of the IES collection have already been catalogued in a database that will be available online in open access after the end of the project "Islam in the Horn of Africa". Among them, about 22 (12\%) contain magic-related materials. For more information on the content and physical description of the manuscripts of the Institute of Ethiopian Studies, see Alessandro Gori et al., A Handlist of the Manuscripts in the Institute of Ethiopian Studies, Eugene, Pickwick, 2014. Both collections have been digitized by the Ethiopic Manuscript Imaging Project (EMIP), directed by Steve Delamarter.

7 The manuscripts numbered IESoo256-IESoo320 were part of this sub-collection, which includes eight of the twenty-two manuscripts of the IEs mentioned in this paper $(36 \%)$.

8 See Ahmed Zekaria, "Some notes on the Account Books of Amir Abd al-Shakur B, Yusuf (1783-1794) of Harar", Sudanic Africa, 8 (1997), 16-36. 
reveal that a number of the manuscripts were, at some point, in different sites in Wallo, where Muslim students from other regions used to go for learning. ${ }^{9}$

Islam was introduced in southeast Ethiopia by Muslim preachers who could provide religious education to the people of the area, thanks to the active trade in books containing Islamic works. In the first/seventh century, the northern part of Ethiopia had its first contact with Islam, and by the second/eighth century, Muslim trading settlements could be found along the coast of the Gulf of Aden and the Somali littoral from which Islam spread gradually into the southeast thanks to the movements of some nomadic groups, like the Afar and Somali migrations from the coast to the interior in the seventh/thirteenth century.10

In his book, Localising Salafism, Terje Østebø notes that Islamic preachers functioned as "diviners with skills in performing miracles" and the combination of Islamic scholarship and esotericism was decisive for the Islamization process in Ethiopia. ${ }^{11}$ Trimingham argued that this characteristic of the Ethiopian Islam brought into the religion of the people a fervor and devotion which could never be achieved by orthodox Islam. ${ }^{12}$ Other factors relevant to the Islamization were, according to Østebø, nomadism and trade, especially that in slaves. ${ }^{13}$ Some communities were Islamized promptly, contributing to the development of local expressions of Islam. ${ }^{14}$ Some elements of the Oromo were also Islamized at an early stage, but others embraced the faith only after having entered those territories in which the population had already converted. The arrival of these Oromo groups in the sixteenth century among these earlier converted communities such as Wallo fostered a process of cultural 'Ajamization which can be referred to as "Oromization", since the host populations adopted certain Oromo traditions. ${ }^{15}$ By the end of the nineteenth century, the majority of the Oromo had converted to Islam but these heterogeneous groups have

9 For further information on the location and history this region, see Hussein Ahmed, Islam in Nineteenth-Century Wallo, Ethiopia, Leiden, Brill, 2001.

10 See Terje Østebø, Localising Salafism: Religious Change among Oromo Muslims in Bale, Ethiopia, Leiden, Brill, 2012, p. 51.

11 Ibid.

12 Spencer J. Trimingham, Islam in Ethiopia, London, Frank Cass, 1952, p. 225.

13 Østebø, Localising Salafism, p. 49-65.

14 Islamic practices are performed in different ways depending of the previous background of the people who adopt them.

15 See Østebø, ibid., p. 62-63; Ahmed, Islam, p. 30, 58-59; Mohammed Hassen, "Islam as a Resistance Ideology among the Oromo of Ethiopia: The Wallo Case, 1700-1900", in the Shadow of Conquest, Islam in Colonial Northeast Africa, ed. Said S. Samatar, New Jersey, The Red Sea Press, 1992, p. 82-86. 
preserved their cultural identity until the present and, due to such complexity, it would be more accurate to speak about a network of cultural influences, exchanges and enrichments rather than of a single process of Islamization. ${ }^{16}$

The spread of the Sufi orders or turuq was a late importation to the religious life in this area, and no țariqa was introduced in Ethiopia until the nineteenth century. Thanks to the spread of the mystical orders Ethiopia experienced a revival of the Muslim faith during the first half of the nineteenth century. The manuscripts analyzed here are the product of this revitalization of Islam in different regions where Saint veneration and the performance of $d h i k r$ were the most widely adopted Sufi practices. ${ }^{17}$

For many Muslims, it has been considered permissible to practice magic and wear protective amulets as long as they are not treated as objects based on powers that emanate from beings independent from God, but as a means of looking for God's protection, since he is the only source of power. ${ }^{18}$ As Sara Fani has remarked, the awareness of this fact is attested in IESoo266 (53r). In this manuscript, a verse of the Qur'ān (Q. 4, 1) followed by a talisman against a plague, deals with the accusation of shirk (polytheism). ${ }^{19}$ This tolerance towards esoteric beliefs, mainly of Sufi Islam, caused some of the non-Islamic religious manifestations of the area to fit perfectly into this kind of religiosity. For instance, the Oromo in Bale used to believe in beings referred to as ayaanotaa, which were distinguishable from God (Waaqa), but equated with Him because they were a part of His essence. According to Gemechu Megersa "an ayanaa causes something to come into being and becomes that which it causes to come into existence" 20 just as the forces represented by the letters

16 As of 2007 Islam was the faith of around $40 \%$ of the population in Ethiopia, representing different ethnic groups such as the Somali, Afar, Argobba, Harari, Berta, Alaba, and Silt'e. It also has many adherents among the Gurage and the largest group in Ethiopia, the Oromo, see Population and Housing Census Report-Country - 2007, Central Statistical Agency, 2010-07, Table 3·3. (Last accessed 11 May 2016).

17 Trimingham, Islam, p. 224, 233-4.

18 Irmeli Perho notes in her article about magic, that the verse of the Qurān (Q. 2, 102) "places magic partly in the domain of the devils, but at the same time it is knowledge that is taught by angels who, by definition, are God's faithful servants," see Irmeli Perho, "Magic in the hadīths", Orientalia Suecana, 61/Suppl. (2012), 183-93, 184.

19 She indicates that it seems to serve as a means of legitimation of what the copyist was about to write. See Sara Fani, "Magic, traditional medicine and theurgy in Arabo-Islamic manuscripts of the Horn of Africa: a brief note on their description", in Essays in Ethiopian Manuscript Studies, eds. Alessandro Bausi, Alessandro Gori, et al., Wiesbaden, Harrassowitz Verlag, 2015, 277.

20 Gemechu Megersa, "The Oromo World-View", Journal of Oromo Studies 12/1-2 (2005), 68-79, 69. 
in the abjad system, as I will explain below. Some scholars have argued that these spirits found their continuity in the jinn, ${ }^{21}$ while Østebø sees a stronger link to the concept of karāma ${ }^{22}$ as a force inhabiting space or as a quality or ability provided by God to certain individuals. ${ }^{23}$ In both the non-Islamic and Islamic Oromo beliefs, certain media are invoked to fulfill specific needs of people; some are spirits of dead people, like the ancestors or $a w l i y \bar{a}$, who are invoked to intercede between the earthly world and God through their ayanaa in a non-Islamic context or their karāma in an Islamic one. ${ }^{24}$

After the Islamization of these heterogeneous communities, the Arabic language and letters acquired a very important role. God's message was revealed in Arabic and thus, this language is clearly connected to Divinity. The Arabic script - the physical manifestation of the language - comprises a sacred but also an esoteric dimension. Letters form words that are part of the essence of material things, but the letters also represent forces that link our world to God. As Fallou Ngom has noted:

Arabic letters (including Arabic numerals) have a holy status in African Muslim areas. They are believed to have spiritual potency and are thus regularly used in prayers, Islamic medicine, numerology, and in the making of amulets such as good luck charms and protective devices [...] Arabic has also been used as the lingua franca of the elite in Muslim communities. For the illiterate masses (who cannot differentiate 'Ajamī texts from Arabic texts) everything that looks like Arabic is regarded as potent, regardless of whether the material is religious or not. Among educated and semi-educated African Muslims, however, 'Ajamī does not have the potency of Arabic nor its holy status. ${ }^{25}$

21 Mario I. Aguilar, "African Conversion from a World Religion: Religious Diversification by the Waso Boorana of Garba Tulla, Kenya", Africa, 65/4 (1995), 525-543; Herbert S. Lewis, Saints and Somalis: Popular Islam in a Clan-Based Society, Lawrenceville, Red Sea Press, 1998, 27 .

22 According to the Encyclopaedia of Islam, in the technical vocabulary of the religious sciences, the term karāma comes to denote the "marvels" wrought by the "friends of God" ( $\left.a w l i y \bar{a}^{\prime}\right)$. These marvels consist of miraculous happenings in the corporeal world, or else of predictions of the future, etc. For more information, see Gardet, "Karāma", $E I^{2}$, 26 January $2017<$ http://dx.doi.org/10.1163/1573-3912_islam_COM_0445>.

23 See Østebø, ibid., p. 88.

24 Ibid., 86-9o.

25 Fallou Ngom, "Murid Ajami Sources of Knowledge: The Myth and the Reality," in From Dust to Digital: Ten Years of the Endangered Archives Programme, Cambridge, UK, Open Book Publishers, 2015, 364 . 
Grammar and tafsir (exegesis) are genres widely cultivated across the whole Islamic world, since the knowledge of the Arabic language leads to a better understanding of the Qurān and thus to a more profound knowledge of God. The interest in cultivating these genres is also very strong among the Muslims who do not have Arabic as their first language. ${ }^{26}$ In Ethiopia this is apparent, since they prefer these genres over others like History or Adab. ${ }^{27}$

\section{Content}

Numbers are the expression of the structure and organization of the universe not only in Islam, but also in other Semitic traditions. Numbers are represented by letters in the abjad system, ${ }^{28}$ where every letter has a specific numerical value and special attributes. Some examples of abjad equivalence tables in which we can see the numerical value of each letter are found in various manuscripts copied sometime in the nineteenth century. These include IES04569 (fol. rr), IES05507 (fol. 2r) and IES05518 (fol. Ir).

The abjad method allows for a calculation of the numerical value of the names of God in order to create purely Islamic protection amulets based on words with similar values, frequently through the employment of magic squares in which the whole universe is said to be represented. Originally, magic squares were mathematical tables, ${ }^{29}$ defined as "harmonious arrangements of numbers" (al-awfāq al-a'dadiyya), and are present in some of the oldest Islamic manuscripts found. ${ }^{30}$ The samples found in the Ethiopian corpus respond to a later development where they are connected to magic and the influence of

26 Muslim territories in Ethiopia reached a very low degree of Arabization, see J. Spencer Trimingham, op. cit., 139.

27 For more information on the role of grammar in this literary tradition, see Alessandro Gori, "The Study of Arabic Grammar in Ethiopia: The Case of two Contemporary Muslim Learned Men", Aethiopica, 11 (2008), 134-147.

28 Numbers are a central aspect of the Jewish Kabbalah tradition, for instance.

29 There exist different theories on the origin of the magic squares. Some scholars argue that they were created in China, and Jacques Sesiano proposes several hypotheses as well, such as the connection of these squares with the introduction of chess in Persia. See Jacques Sesiano, "Construction of Magic Squares Using the Knight's Move in Islamic Mathematics", Archives for the History of Exact Sciences, 58 (2003), 1-20.

30 The study of these squares was known as hisāb al-waqf (calculation of the harmonious arrangement), and this points out to their mathematical origin as well. See Mercé Comes, Rosa Comes, "Los cuadrados mágicos matemáticos en al-Andalus: El tratado de Azarquiel", al-Qanțara, 30/1 (2009), 137-169, 143. 


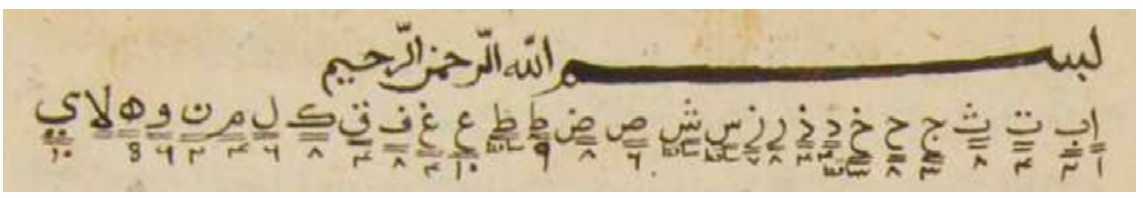

FIGURE 1 Abjad. IESO1853 (fol. $3 r$ ). In this sample the letters of the abjad are ordered according to the modern alphabet instead of following the traditional order. ${ }^{31}$

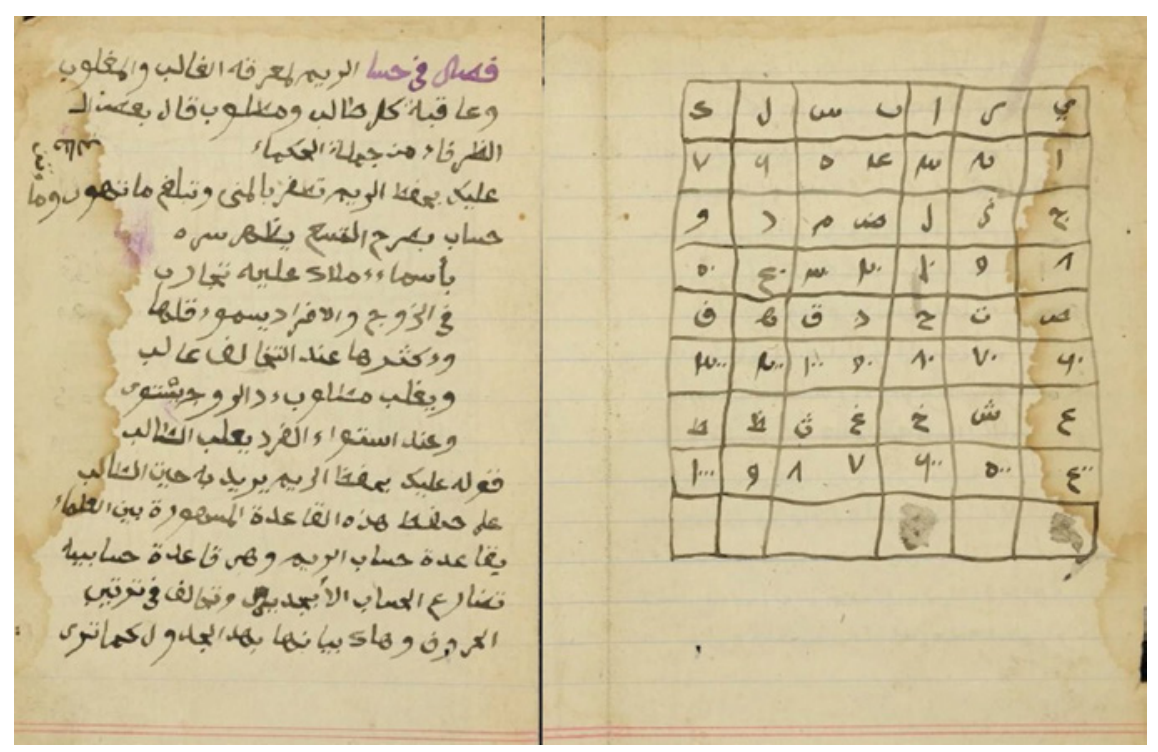

FIGURE 2 Magic Square. WEINERooo53 (loose folio)

the planets. Following what Mommersteeg explains in his article on the fabrication of an Islamic love-amulet in West Africa, "magic squares are a way of writing which eases the communication with the beings holding the proverbial keys to linking the microcosm with the macrocosm it represents". ${ }^{32}$

According to Mommersteeg, these beings can read the squares and immediately understand what is being requested. For the elaboration of a protective amulet through this method, a suitable word must be chosen, since not all of them are eligible, but it can be a Divine Name, a verse of the Qurān or any other Arabic word or text. In relation to this subject, the manuscript IES00272

31 The images are courtesy of Professor Steve Delamarter (Director of the EMIP project), the Institute of the Ethiopian Studies and the owners of Weiner collection; Mrs. Barbara Weiner and Mr. Gerald Weiner.

32 Geert Mommersteeg, "He Has Smitten Her to the Heart with Love: The Fabrication of an Islamic Love-Amulet in West Africa", Anthropos, Bd. 83, H. 4/6 (1988), 501-510, 505. 
is entirely devoted to works dealing with the science of letters, magic squares and the names of God. ${ }^{33}$ In addition to al-Būnì's (d. 622/1225) al-Nūr al-asnā fì sharh al-asmä al-husn $\bar{a}^{34}$ we also find two other works in the same codex, that provide us with several examples of magic squares..$^{35}$ One of them is Bahjat al-țarf fi ' Im al-harf of Ibn Qurqmās al-Qāhirī al-Ḥanafì (d. 881/1477) and the other one is Kitābfi 'ilm al-arqām wa-l-awfāq, which is a short text by an unknown author. The manuscript IES00280 also contains a $d u^{\prime} \bar{a}^{\prime}$ dealing with the names of God and the achievement of concrete purposes through the employment of talismans built by the calculation of their numerical value. Its title is al-Jawshan al-kabìr and it is attributed to 'Alī b. Abī Țālib. ${ }^{36}$

The names of God describe only a part of His essence. His greatest name remains hidden and only prophets and saints have access to its knowledge. This name is not represented by letters, but by a group of symbols referred to as the "Great Seal" among which the six-pointed or five-pointed star is the principal symbol. These symbols are said to protect against the evil of humans and jinn as in the case of the magic scroll IESoo6 $47 .{ }^{37}$ The Great Seal has also been referred to as Solomon's seal or the seven seals of Solomon, but sometimes we find that the term "Solomon's seal" refers only to the star, the power of which is derived of its status as one of the symbols representing the hidden name of God. ${ }^{38}$ The isolated star-in both its five-pointed and six-pointed versions - appears in different manuscripts such as WEINERoooll (fol. ir, iir, iiir), WEINERooo39 (fol. 1r), WEINERooo61 (inner lining of the front cover), WEINERoo128 (inner lining of the front cover), IESoo280 (fol. 4r), IESoo286 (fol. 16r-17v), IES05507 (fol. 1r) and IES05521 (fol. 181v).

Cryptography is frequently employed as a method of preserving the esoteric knowledge in the examined texts. Apart from the abjad, ${ }^{39}$ several different

33 See Sara Fani, op. cit., 274.

34 The Egyptian scholar, al-Būnī, wrote this and other treatises such as "Shams al-ma'ärif al-kubrā," which would become the source for all kinds of magic related to the names of God. See Edmond Doutté, Magie et Religion dans l'Afrique du Nord, Paris, Librairie d'Amérique et d'Orient Adrien Maisonneuve, 1983, 199-219.

35 In this codex, we find complete works related to the magic squares, and we also find loose magic squares in the manuscripts WEINER 00053, IES00282 and IES00299.

36 See Fani, op. cit., 275 .

37 I will talk again about this item when discussing Figure 7.

38 For more information, see Ruska, Carra de Vaux- [C.E. Bosworth], "Tilsam", in Encyclopaedia of Islam, Second Edition, eds. Bearman, P.; Bianquis, Th., Bosworth, C.E.; van Donzel, E.; Heinrichs, W.P., Brill Online, 2016, o7 May $2016<$ http://referenceworks.brillonline .com/entries/encyclopaedia-of-islam-2/tilsam-SIM_7553>

39 The will of hiding information from the people out of the community is also observed in relation to mundane information, like names and dates, an example of chronogram to 




FIGURE 3 Secret alphabets. IESOO280

secret alphabets have been used in the corpus with this purpose of knowledge preservation, but they are not different from other secret alphabets employed in diverse Islamic societies. ${ }^{40}$ Some of the letters or symbols found in IESo0274 (fol. 41r), IESo0280 (fol. 6v), IESo0286 ${ }^{41}$ and IES01856 (fol. $3 \mathrm{r}$ ), ${ }^{42}$ for instance, have certain similarities to the alphabet called qalam al-țayr and other secret alphabets mentioned by Gacek in his Vademecum. ${ }^{43}$ The symbols "in eyeglasses"

express a year (غ392/1972) is found in the manuscript number 3 of the collection of the Zabbi Molla library in Wolkite (Gurage zone), which is currently being catalogued by the project Islam in the Horn of Africa. For further discussion on the potency of letters and numbers and their use in chronograms, see Ngom, "Murid Ajami Sources," ibid., 364.

40 See similar secret alphabets in Ana Labarta, Libro de dichos maravillosos: misceláneo morisco de magia y adivinación, Madrid, CsIC, 1993, 038.

41 We find examples of cryptography in almost every page.

42 The date of copy (1104/1693) is specified in the colophon (181v). It is the third oldest manuscript of the IES collection, but unfortunately we do not know where it was copied.

43 Adam Gacek, Arabic Manuscripts: A Vademecum for Readers, Leiden, Brill, 2009, 246. 
that we find for instance in IESO0280 (fol. 7r), which are common to both Christian and Islamic talismans, are also found in Greek, Coptic, Aramaic and Hebrew texts and amulets since the second century CE. Chernetsov explains that professional scribes in Ethiopia describe these symbols as leg-fetters trapping demons in place. ${ }^{44}$

Another typical means of preserving the esoteric knowledge in this magicrelated material is the omission of relevant information such as the instruction for a talisman, but omission is not restricted to the Ethiopian case as demonstrated, for instance, by Fallou Ngom, who detected the employment of this method of concealment in Islamic esoteric material from Senegal. ${ }^{45}$

The Basmala, the names of the angels ${ }^{46}$ and some of the verses of the Qura'n are used as protection amulets, not only through the employment of magic squares, but also directly as quotations. An example of Qur'ānic verses used as amulets is that of al-mu'awwidatān (the two that preserve), that are the two last süras. In both süras an expression that has been employed for invocations against different evils can be found: "I take refuge..." (a'üdhu). These kind of invocations turn up, for example, in WEINER00136 (fol. 126v) and WEINERoo186 (fol. $49 \mathrm{r}) .47$

In relation to the specific case of the Basmala, we find plenty of samples written in the manuscripts, but it is hard to distinguish whether the aim is magical protection in every case. This is because this formula was used for the composition of talismans and it also customarily starts every composition of a devotional text, showing the blurring line between religion and magic. The fact that in IES00280 (fol. 32v), which is a manuscript partially devoted to magic, the Basmala appears in the folio next to the one containing an invocation to Prophet Muhammad (fol. 31v) could be a clue to consider this sample as a protective formula.

Sürat al-Fätiha (the opening chapter of the Qur'ān) constitutes a special case among the verses of the sacred text, since its power has to do with the hidden name of God. There are seven letters (فن ظ شخ خج ث), which do not appear in sürat al-Fätiha and this has been interpreted as a sign of the link between

44 See Sevir Chernetsov, "Ethiopian Magic Texts", Forum for Anthropology and Culture, 2 (2005), 188-200, 189, 192; C.Thomas McCollough \& Beth Glazier-McDonald, "An Aramaic Bronze Amulet from Sepphoris", 'Atiqot, 28 (1996), 161-165.

Ngom, "Murid Ajami Sources", ibid., 359-360.

$46 \quad$ IESO0272 (17v).

47 For more information, see Ruska, "Tilsam", $E I^{2}$, 29 August $2016<\mathrm{http} / /$ dx.doi.org/10.1163/ 1573-3912_islam_SIM_7553>. 


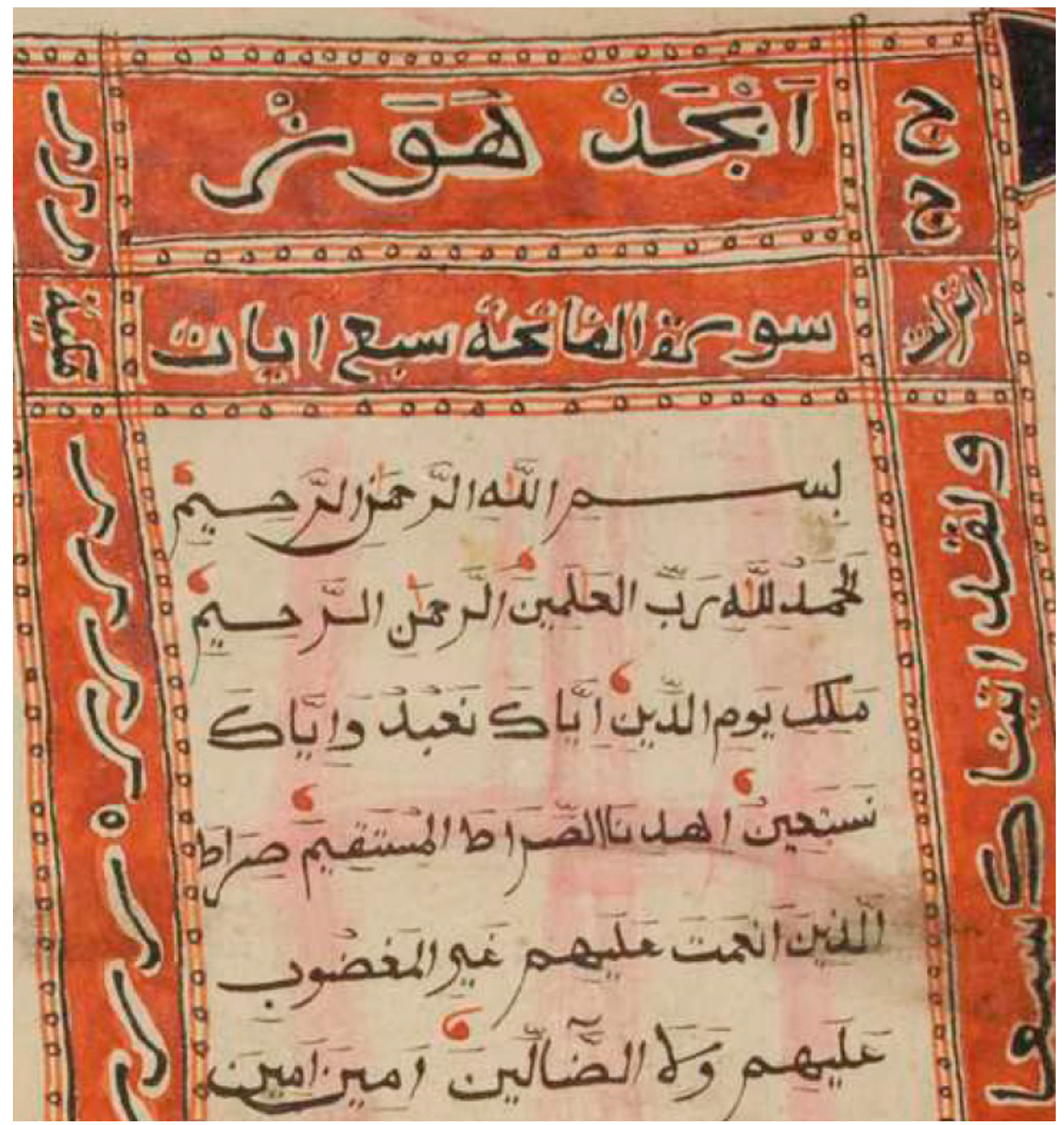

FIGURE 4 Fātiha with abjad letters in the frame. IESo4589 (fol. w)

them and the seven symbols representing the hidden name. The first süra of the Qurān seems to be used as an amulet in WEINER00065 (fol. ir) because it is repeated in the folio iv and in IESO4589 the frame contains the abjad alphabet. In the manuscript WEINERoooo1 (fol. 6or), copied in (1189/1775), there is a text on the magical properties al-Fätiḩa.

With respect to the purposes of the talismans, I have distinguished two types of texts: first, amulets providing protection and second, texts containing instructions to construct talismans in order to prevent and heal concrete evils. The former are simply invocations to powerful forces and their aim is often the protection of the books in which they are copied. The search of God's protection 
is linked to symbolic rituals like prayers, while the second category seems to be the result of a later development. According to Sørensen "existing symbolic rituals were changed to more goal-oriented actions". 48 These goal-oriented actions encompass protection and solution to diverse sorts of problems, including medicine and healing. This sort of texts constitute a good example of the way in which the content can provide us with information about the 'Ajamization of Islam in Ethiopia, since the concerns related in the materials reflect the belief system of the Ethiopian Muslim society. The problems and needs of the Ethiopian Muslims necessarily condition the kind of amulets that will be created. In addition, the same concerns are shared by Muslims and non-Muslims, showing that the 'Ajamization thesis transcends Islam, comprising also Christianity. Among the material found, it is possible to find instructions to create talismans with diverse purposes like stimulating lactation in animals in IESO0304 (fol. 92r-92v); making people obey the person wearing it, sleeping, defeating the heat and the plague of smallpox, etc. in IESooz66

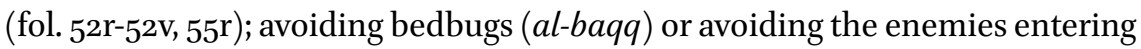
one's house in IES04562 (fol. 1V, 93r), preventing birds from eating the sowing in IES 04561 (fol. 101v-102r) and so on. Other purposes found in these texts have

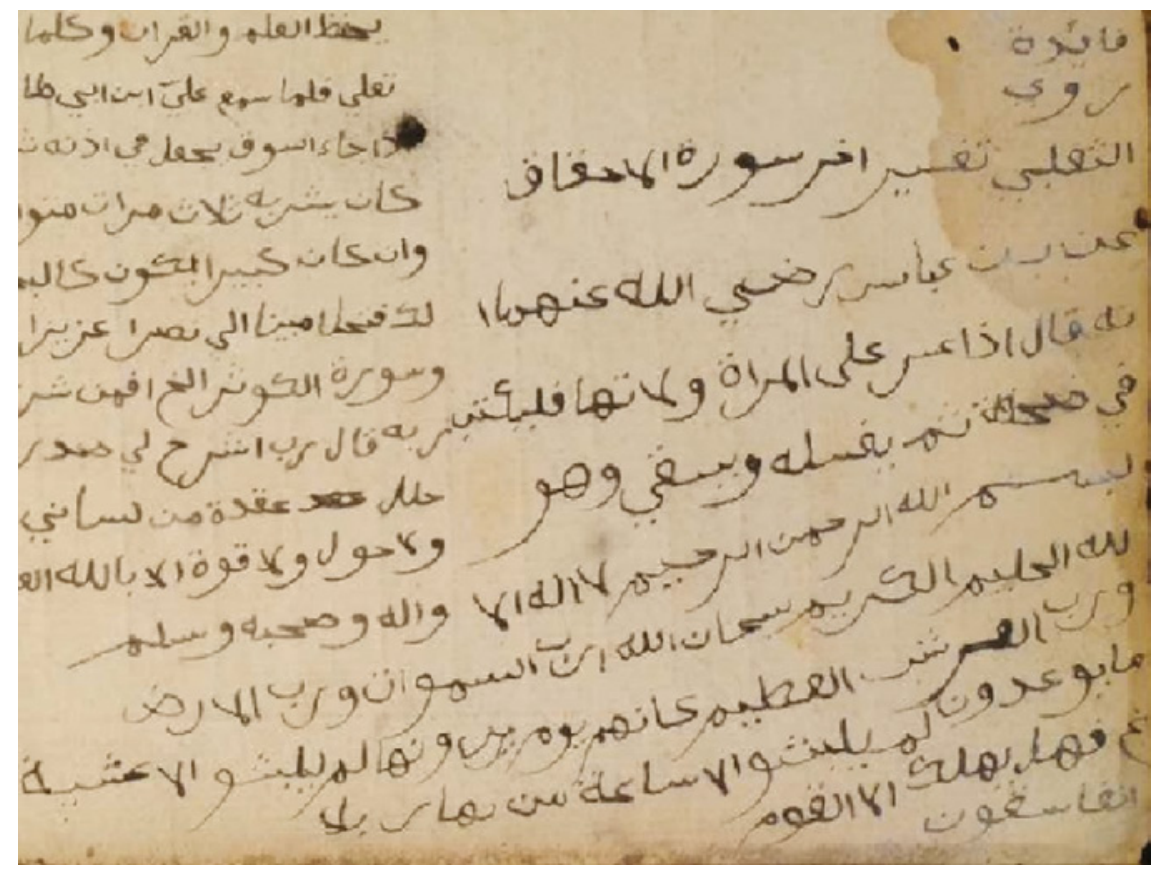

FIGURE 5 Instructions for an amulet to ease difficult births in the ms. WEINERooor3 (fol. 97r)

48 Jesper Sørensen, A Cognitive Theory of Magic, Plymouth, Altamira Press, 2007, 190. 


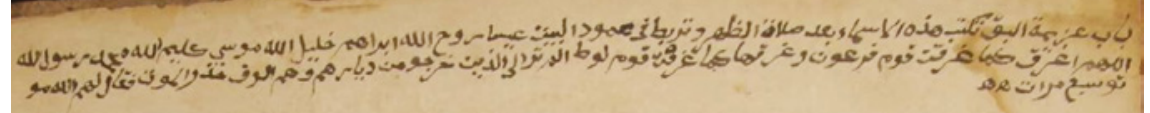

FIGURE 6 Instructions for an amulet to avoid bedbugs in the ms. IESo4562 (fol. $w$ )

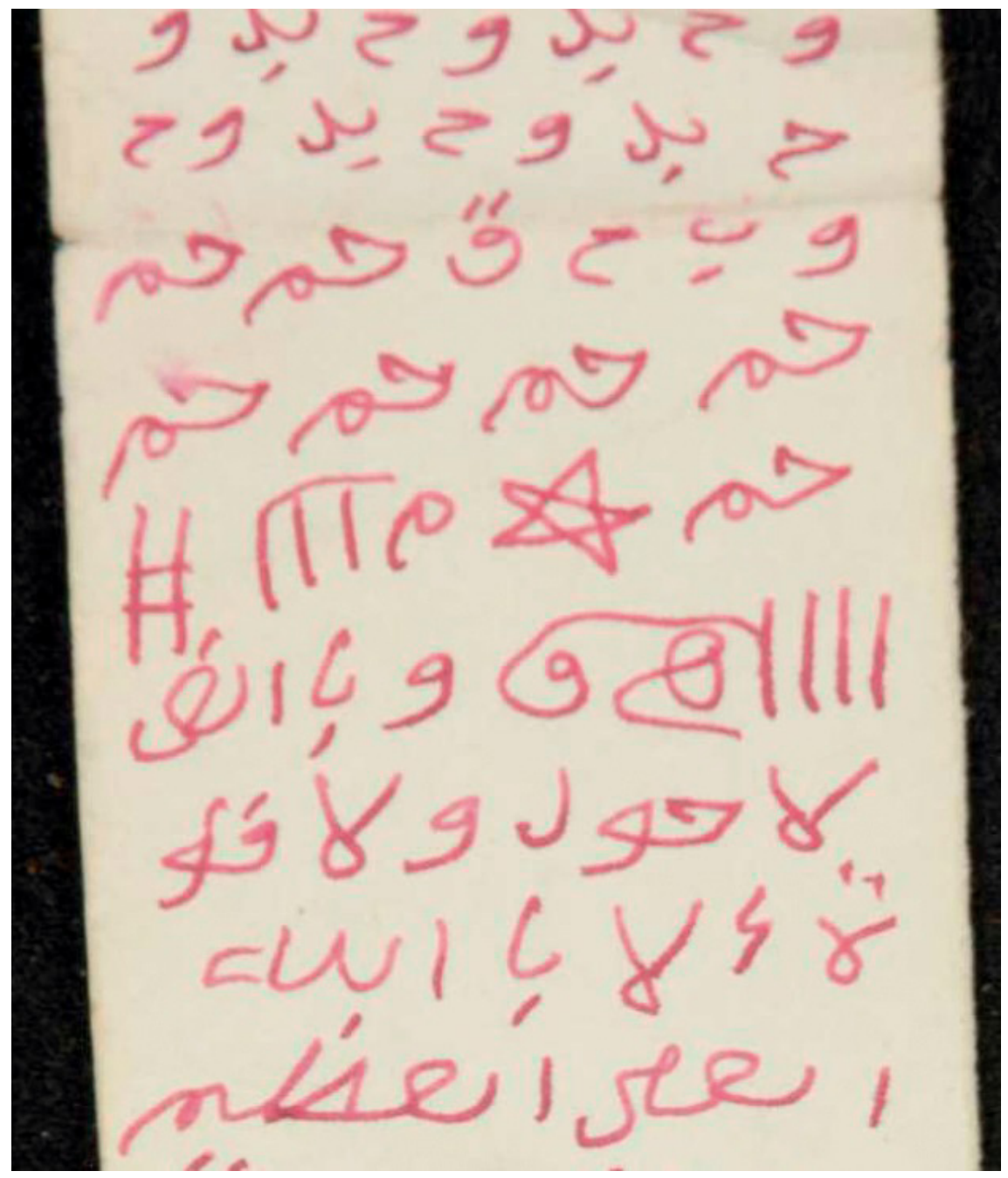

FIGURES 7 AND $8 \quad$ Magic scrolls (mss. IESoo647 and IESoo648).

been described by Sara Fani, such as becoming invisible and walking on water in IESO2640 (fol. gv)..$^{49}$ 


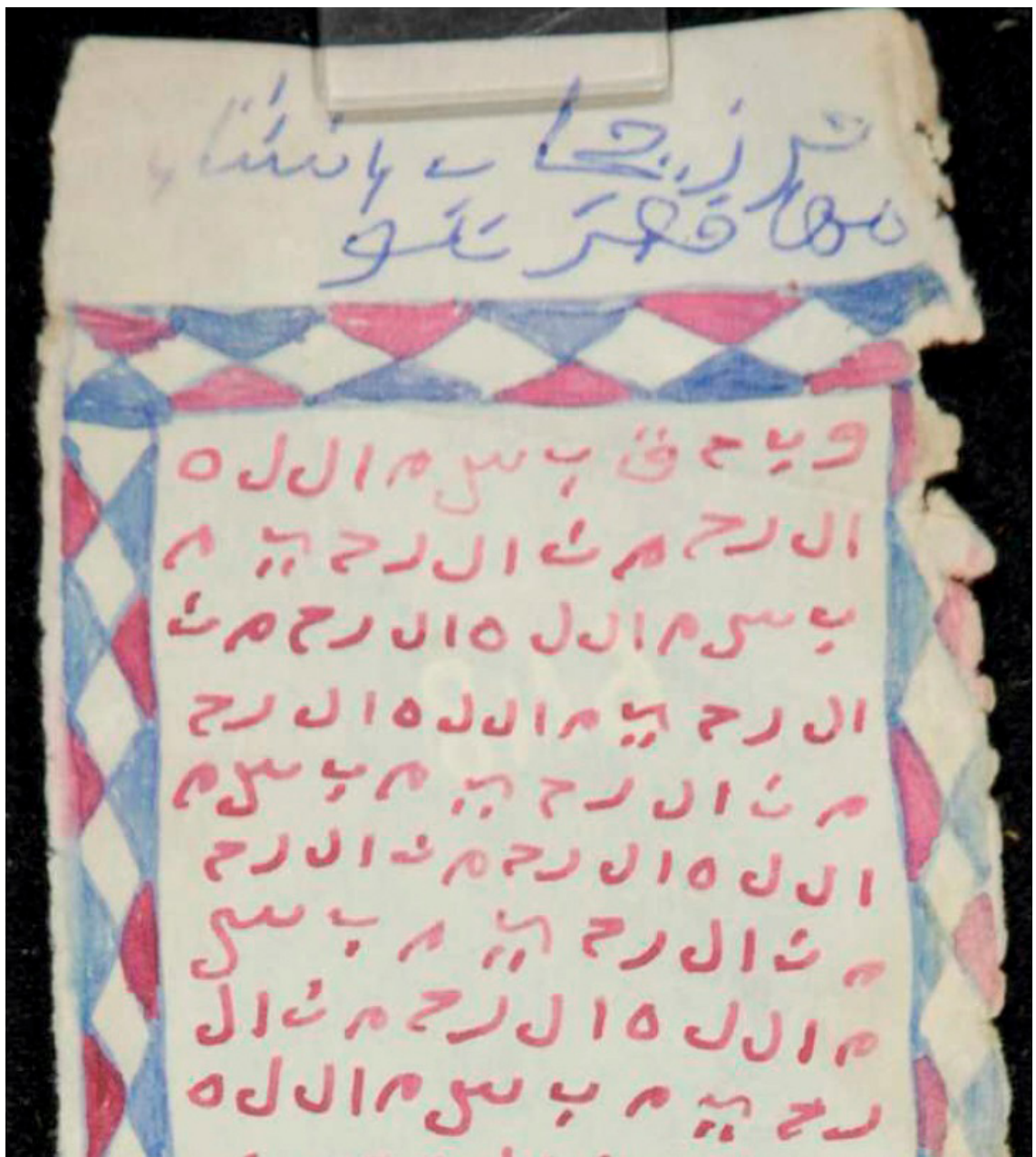

FIGURES 7 AND 8 (Continued).

Both protection amulets for the books and instructions to construct healing amulets are easily found in the manuscripts under consideration. They usually appear as marginal notes copied in manuscripts dealing with Sufi devotional literature..$^{50}$ However, it is not so easy to find actual amulets prepared for being

50 That is the case of the following manuscripts WEINERoo151, WEINERoo187, WEINERoo19o, IESO0282, IESO0304 and IES004520, among others. Though less frequent, they are also found in codices containing works related to other subjects like jurisprudence, as in the case of IES04573, which contains an invocation to Kabīkaj (1r) and al-Nawawìs (d. 676/ 1277) Minhāj al-țālibìn. 
worn, kept or hung elsewhere. ${ }^{51}$ The only two samples are the magic scrolls IESoo647 and IESoo648, which are amulets against the evil of humans and jinn. Nonetheless, the use of the scroll format is well attested in Ethiopia. Both Christians and Muslims have widely employed them, although the preferred support among the Christians is parchment, while Muslims use paper. ${ }^{52}$ In relation to this common feature between Christians and Muslims, it must be noticed that much of the Christian magical literature has been influenced by and even partly translated from Arabic books on magic,53 in addition to the Awda Negast, the Ethiopian book on fortune telling, ${ }^{54}$ Abraham Demoz provides us in one of his articles with several samples that illustrate the Islamic influence in the Christian magic-related texts..$^{55}$

The texts found in the codices are the final result of a process of creation for which details are lacking. As I mentioned before, the omission of information is not something unique to the Ethiopian tradition, but it is a common means to secure the secrecy of knowledge in Sufi communities, where only the one initiated in a tariqa has the right to know certain things. ${ }^{56}$ When amulets are copied from another manuscript, the copyist does not necessarily have to know the process of creation or the origin of such item or ritual. This would eventually lead to the diffusion of amulet-making among lay people and to the widening of their magic uses in time. Even when we find isolated instructions to create talismans, we do not know the reasons behind the steps that must be taken. As John Martin pointed out in his thesis on theurgy in medieval Islam:

In pre-modern treatments, theurgy is confusing to parse as it represents, for some writers on the topic, the highest form of mystical achievement. As such, its secrets are meant to remain hidden, and while extensive information may be given in the textual tradition, much of it is vague or misleading, meant as a test to weed the uninitiated from the adept. The material culture is no less

51 Chernetsov, op. cit., 189.

$5^{2}$ This difference is present not only in talismans, but also in every other type of manuscript. See Anne Regourd, "Introduction to the Codicology: Papers, Ruling, and Bindings", in Gori, $A$ handlist, xlvii-xcii.

53 See Trimingham, op. cit., 28; Chernetsov, op. cit., 188; Mercier, Jacques, Ethiopian Magic Scrolls, New York, G. Braziller, 1979.

54 Carlo Conti Rossini, “Lo 'Awda Nagast Scritto Divinatorio Etiopico”, Rassegna di Studi Etiopici, 1/ 2 (1941), 127-145.

55 Demoz detected the use of Arabic even for Christian expressions in magical works. See Abraham Demoz, "Moslems and Islam in Ethiopic Literature", Journal of Ethiopian Studies, 10/1 (1972), 1-11, 4-5.

56 Ngom, "Murid Ajami Sources”, ibid., 359-6o. 
vague, as it represents the completed material product of the working of theurgic rites, ostensibly, but gives no insight into the spiritual, which is the actual realm of theurgy. ${ }^{57}$

The adverse effect of this process is that esoteric power is directly associated with the physical presence of the letters and the process itself loses its meaning, leading to the corruption of the original amulets as I will explain below. The loss of meaning can happen in every type of talisman like the budūh, which is "an artificial talismanic word formed from the elements of the simple three-fold magic square expressed in Abjad",58 but it is especially noticeable in the case of the invocation to Kabikaj. ${ }^{59}$ The kabikaj is a venomous plant ( $r a-$ nunculus asiaticus) described in the De materia medica of Dioscorides, which was placed inside the books, ${ }^{60}$ preserving them from bibliophagous bugs. In a later development, Kabikaj was identified with a jinn who could protect the codices and he started to be invoked most of the time, employing the formulas: Yã Kabīkaj ihfaz or Kabīkaj, yā hafiz. ${ }^{61}$ We have found several of these invocations to Kabikaj in the Ethiopian manuscripts, but one of them seemed to me especially meaningful. In the manuscript WEINER00020 (fol. 182v), the letters are separated and copied in a wrong order, the letter " $b \bar{a}$ " and the letter " $y \bar{a}$ " are inverted, forming "kïbkaj" instead of "kabikaj". In my opinion, this corruption is an example of a text copied by a scribe who did not really know what he was writing, especially since the mistake occurs more than once. This probably means that he copied the text from an original in which the same mistake had already been made. It may be that the copyist did not know the meaning of the word, but he did know the protective power attributed to the specific combination of letters which he then tried to reproduce. Nevertheless the order of the letters could have been changed on purpose with the aim of making the jinn act in certain way, since reversing the natural order of letters and verses is often employed as a method to unleash negative supernatural power.

57 Although John Martin is specifically referring to theurgy, it is a valid affirmation for other types of magic as well, John D. Martin III, Theurgy in the Medieval Islamic World: Conceptions of Cosmology in al-Bünìs Doctrine of the Divine Names, Cairo, The American University, 2011, 1-2.

58 See David Bruce MacDonald, "Budūh", $E I^{2}$, 11 May $2016<$ http://referenceworks.brillonline .com/entries/encyclopaedia-of-islam-2/buduh-COM_1395>.

59 I have capitalized the term only when it refers to the name of the jinn.

6o Adam Gacek, "The Use of Kabīkaj in Arabic Manuscript", Manuscripts of the Middle East, 1 (1986), 49-53.

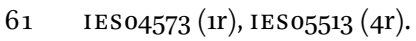




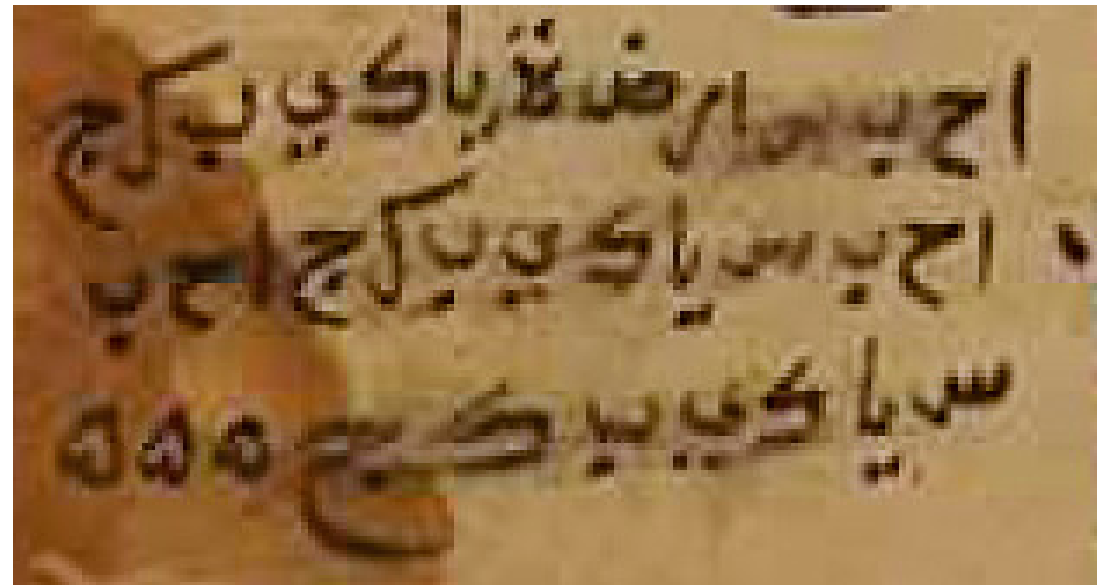

FIGURE 9 Invocation to Kabìkaj in the ms. WEINEROOO2O (fol. 182v)

In the amulet in fig. 9, the letters are written in their isolated forms. According to Tewfik Canaan, the isolated forms were used in amulets to invoke separately the power of each letter, thus maximizing the effect of the charm. ${ }^{62}$ The information on the origin of these samples is missing, but it is possible to learn more about the talisman-making process through complete works like alBūnì's aforementioned al-Nūr al-asnā. It is also possible to find other types of magic-related texts such as invocations to jinn ${ }^{63}$ or fragments dealing with

62 See Tewfik Canaan, "The Decipherment of Arabic Talismans", in Magic and Divination in Early Islam, ed. Emilie Savage-Smith, Aldershot, Ashgate Variorum, 2004, 125-177, $15^{2}$. Another purpose of using isolated forms is noted by Fallou Ngom. According to him, the letters are written in their disconnected form in some Hausa 'Ajamī texts in order to remove their sacredness when the texts are intended for a non-Muslim public, see Ngom, "Ethics over Ritual" (chapter 2), Muslims beyond the Arab World, n. 108.

63 The manuscript IESOo286 contains a description of the jinn tribes and the charms that have to be used to chase them away, including drawings of their respective kings. This is a work which was also found by Anne Regourd in a Yemeni manuscript dated around the eighteenth or nineteenth century. See Fani, op. cit., 275; Anne Regourd, "Le Kitāb al-Mandal al-Sulaymānī, un ouvrage d'exorcisme yéménite postérieur au Ve/xıe s.?”, in Démons et merveilles d'Orient, Res Orientales, 13, ed. R. Gyselen, Bures-sur-Yvette, Groupe pour l'étude de la civilisation du Moyen-Orient, 2001, 123-138; "Images de djinns et exorcisme dans le Mandal al-Sulaymān̄̄, in Images et magie. Picatrix entre Orient et Occident, Sciences, techniques et civilisations du Moyen Âge à l'aube des Lumières, 13, eds J.P. Boudet et al., Paris, Honoré Champion, 2011, 253-294. 
astrology and divination. ${ }^{64}$ Following Toufic Fahd, ${ }^{65}$ Sara Fani has suggested that in contrast to theurgy, magical practices related to demons and jinn are "black magic",66 but taking into account that esoteric knowledge was reserved for selected people, this sort of magic had to be practiced by the same people cultivating theurgy, so that this literature on demons and jinn, although hypothetically rejected by Islam, is also the product of an Islamic context. ${ }^{67}$ It has to be noticed that - as in the case of the term "theurgy" - the distinction between white and black magic originated in an European/Christian context and in Islam these distinctions are not that clear. Even in the cases in which some rituals are considered to be outside of the dogma, they can become accepted as valid in some circles. Irmeli Perho noted the following in this respect:

Magic is a competing source of efficient rituals, and the competition leads to a conflict between controlled authorized ritual actions that are based on established religious doctrine, and magical practices that are uncontrolled, representing an alternative ritual context. ${ }^{68}$

Jesper Sørensen proposes appropriation, rejection and segregation as the three possible reactions of the religions towards magic. ${ }^{69}$ Appropriation is represented by theurgy, while segregation would define the status of certain rituals that are practiced in spite of being considered outside the framework of dogma. Similarly, in the Ethiopian Christian context, the amulet-wearing and the practice of magic in general was forbidden by the Church, but Chernetsov has shown that in spite of the ban on magic by the Ethiopian Church, "the clergy, as the only literate stratum of society, has been uniformly responsible for copying the texts and disseminating the amulets containing them." ${ }^{70}$

64 In WEINERoo151 (36r-37v) there is a text about knowing how the year will be only by observing the month of Muharram, which is the first of the lunar calendar. Some other notes on astrology and divination based on moon phases can be found in IESo0304 (100r-101v) and WEINEROOIgo (37r).

65 Toufic Fahd, "Magic: Magic in Islam", tr. from French by D.M. Weeks, in The Encyclopedia of the Religion, ed. M. Eliade, New York, Mac Millan, 1987, IX, 104-109.

66 Fani, op. cit., 277.

67 In fact, the existence of these beings is attested to in the Qurann, but communication with them is only considered positive in Islam when it does not imply the acceptance of powers other than that which emanates from God, as mentioned earlier, see Q 2:102.

68 Perho, op. cit., 184.

69 Sørensen, op. cit., 13.

70 Chernetsov, op. cit., 188. 


\section{Problems found and Concluding Remarks}

As mentioned previously, given the lack of esoteric texts written in 'Ajamī, ${ }^{71}$ the 'Ajamization in this kind of material has to be studied from other aspects such as aesthetics and content. The first problem found in relation to the aesthetics is that the samples in our corpus are not artistic manuscripts in general. There are very few illuminations, mostly found in the copies of the Qur'an, ${ }^{72}$ and it can be said that, apart from few exceptions, the texts are not beautifully presented. One could think that beautiful codices would have been cherished and preserved, and their absence indicates that they never existed. Instead, the Ethiopian manuscripts seem to have been objects used in daily religious life and the external appearance was not a priority for scribes. This neglect of

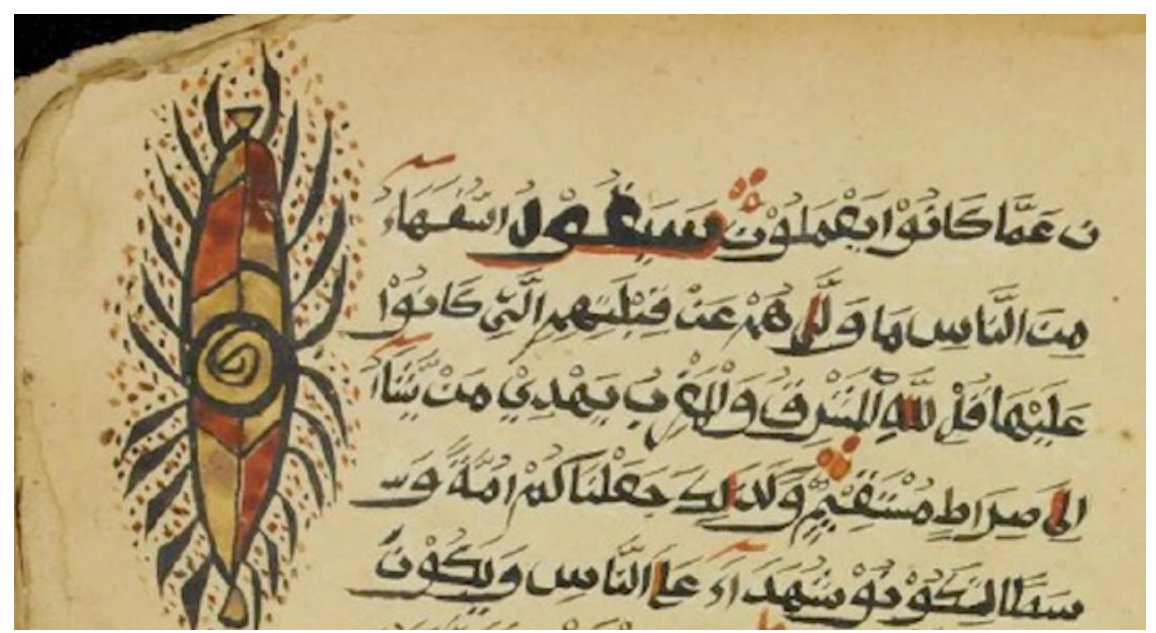

FIGURE 10 African shields as juz' markers of the Qur'ān in the ms. WEINERO0201 (fol. 14r)

71 For a general overview on 'Ajamī literature in Ethiopia, see Alessandro Gori, "Lingua, scrittura e religione in Etiopia: un testo islamico amarico in grafia araba", in XII Incontro Italiano di Linguistica Camito-semitica (Afroasiatica), ed. Marco Moriggi, Soveria Mannelli, Rubettino Editore, 2007, 243-54; Andreas Wetter, "Rhetoric Means of a Didactic Amharic Poem from Wärrä Babbo", Aethiopica, 15 (2012), 176-203.

72 The illuminations in the books are usually a unique source of local peculiarities. A good example of 'Ajamization can be found in WEINER00201, since juz' markers in this copy of the Qur'ān are African shields. Another example is the illuminated frame with crosses decorating Sūrat al-Fātiha and the beginning of Sürat al-Baqara in the Qurān contained in WEINERoo136, edging that the decorative motif could have been copied from a Christian manuscript. 
aesthetics - that may just have been the result of the lack of resources-in addition to the abundant glosses that we find added in the margins of most of the codices, indicate they were the result of dynamic intellectual and teaching activity, and the aim of copying the texts was the study and analysis of the contents or their practical employment for rituals, without any kind of commercial purpose.

Thus, in relation to the aesthetics of the analysed material, the only detected peculiarity is the use of scrolls in the manuscripts IES 00647 and IESoo648. As I pointed out before, scrolls are not frequent in the corpus employed for the elaboration of the present paper, since these are the only two samples found until now, but their use is well attested among Ethiopians. Perhaps the reason for the absence of scrolls in the materials is simply that talismans were meant to be used or worn and not merely read. Given the use of the scroll format among both Christians and Muslims, we can see common features in relation to esotericism and magic transcending the barriers between Islam and Christianity, probably in both directions.

The second problem came up in relation to the content of the amulets instructions. The amulets produced in a community reflect their specific problems, and the amulets in our corpus refer to rural communities where the protection of the crops and livestock, fertility and the struggle against illnesses and plagues were the main issues of concern. The major problem is that these issues are not exclusively Ethiopian but are encountered in other societies as well. Therefore, only amulets mentioning local flora and fauna that are not found elsewhere can be identified as definitely Ethiopian and thus as examples of the enrichment of the Islamic magical tradition with specific local features. I have not found an example of such a peculiar animal or plant up to now, but it could appear sometime during the analysis of further Ethiopian collections.

The conclusion drawn from this research, therefore, is that the talismans retrieved from Ethiopian Islamic sources represent the holiness and the power of the words linked to the Divinity and, as such, the amulets share form and content with the amulets created within diverse Islamic literary traditions. Østebø's research in Bale has proven the existence of a parallel universe of Oromo beliefs. ${ }^{73}$ However, this parallel universe is not reflected in the esoteric material. The question that arises is: why is this the case?

Predisposition to esotericism seems to be a local feature present before the arrival of Islam, but the esoteric material is fully Islamic in its appearance. Østebø has explained this phenomenon: 
Islamic texts were invoked, interpreted and transmitted in a manner that contributed to maintaining conformity to Islamic literary traditions yet at the same time embedded with and related to a local universe in which the esoteric dimension and so-called magical usage remained in an intrinsic aspect. ${ }^{74}$

Trimingham explained that "superstition" and magic pervade Ethiopian Islam, showing the influence of the Kushite "paganism". According to him, Muslims gave orthodox interpretations to their rites and justified them by referring to Islamic legends. ${ }^{75}$ Shrines were centers for the performance of Sufi rituals, but also centers for teaching which promoted a tradition of literacy and conformity to Sunni Islam. ${ }^{76}$ The aim of fitting their traditional magic practices into Sunni Islam and the sacred character of the Arabic language are probably the two main reasons why the analyzed Ethiopian esoteric manifestations show very few local features. As elsewhere in the Islamic world, the main esoteric materials are the abjad system, the magic squares, the names of God, the Solomon's seal and amulets and invocations related to jinn. ${ }^{77}$

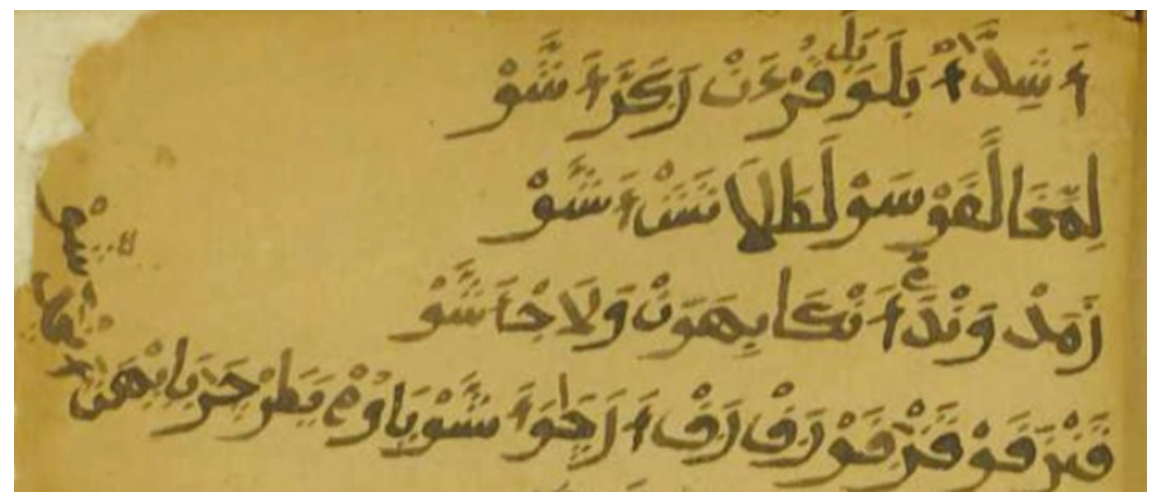

FIGURE 11 Fragment of a Takhmīs in Ajami in the ms. WEINERo0141 (fol. $w$ )

74 Ibid., p. 40. He based his arguments on the research carried out by Louis Brenner and Jack Goody. See Louis Brenner, "The esoteric Sciences in West African Islam”, in African Healing Strategies, eds Brian M. du Toit and Ismail H. Abdallah, Owerri, Trado Medic Books, 1985; Jack Goody, "Restricted Literacy in Northern Ghana", in Literacy in Traditional Sciences, ed. Jack Goody, Cambridge, 1968.

75 Trimingham, ibid., p. 225.

$76 \quad$ Østebø, ibid., p. 51; Hussein, ibid., p. 94.

77 For example, they appear in manuscripts from western Africa, see Dilley, Roy M., Islamic and Caste Knowledge Practices among Haalpulaar'en in Senegal: Between Mosque and Termite Mound, Edinburgh, Edinburgh University Press, 2004. 
According to the results of this study, the distinctiveness of Ethiopian Islam seems to be more evident in rituals and practical actions $;{ }^{78}$ while the texts tend to follow the Islamic mainstream. ${ }^{79}$ That could be the reason why the 'Ajami texts found in these two collections of Ethiopian Islamic manuscripts are religious texts used in devotional rituals whereas texts on theoretical subjects such as figh are written exclusively in Arabic. The manuscript WEINERoo141, for instance, contains poems written in 'Ajamī (Amharic written in Arabic script) probably composed for the celebration of Prophet Muhammad's birthday, since they are preserved together with an Arabic takhmis on the Witriyya, a poem which is traditionally recited during the celebration of the mawlid. The 'Ajamì texts seem to be an aide memoire of what has to be recited during the rite.

Given the complexity of the heterogeneous religious manifestations in Ethiopia, the process of cultural 'Ajamization in relation to esotericism should be studied from different perspectives to obtain a complete picture. Other types of methodological approaches such as archeology or anthropology could provide valuable and complementary information on the local peculiarities. An interdisciplinary approach combined with the study of the devotional texts written in 'Ajamī could shed light on some aspects that remain concealed. Furthermore, the analysis of the texts that until now remain unidentified in the two collections I examined and the content of other collections, nevertheless, could lead us to discover locally composed texts that would complement the information on the distinct character of local Islam in relation to esotericism in different Ethiopian communities. ${ }^{80}$

78 See Østebø, ibid., p. 83-125.

79 Sørensen defines magic as action and not a system of thought. See Perho, ibid., p. 184; Sørensen, ibid., p. 13.

8o I would like to thank Irmeli Perho and the reviewers for their advice during the elaboration of this article. 